\title{
66. EVIDENCE FOR LATE MIOCENE CYCLICITY AND BROAD-SCALE UNIFORMITY OF SEDIMENTATION IN THE YAMATO BASIN, SEA OF JAPAN, FROM FORMATION MICROSCANNER DATA ${ }^{1}$
}

\author{
Jeffrey A. Meredith ${ }^{2}$ and Ryuji Tada ${ }^{3}$
}

\begin{abstract}
During Leg 127, the formation microscanner (FMS) logging tool was used as part of an Ocean Drilling Program (ODP) logging program for only the second time in the history of the program. Resistivity images, also known as FMS logs, were obtained at Sites 794 and 797 that covered nearly the complete Yamato Basin sedimentary sequence to a depth below $500 \mathrm{mbsf}$. The FMS images from these two sites at the northeastern and southwestern corners of the Yamato Basin thus were amenable to comparison.

A strong visual correlation was noticed between the FMS logs taken in Holes 794B and 797C in an upper Miocene interval (350-384 mbsf), although the two sites are approximately $360 \mathrm{~km}$ apart. In this interval, the FMS logs showed a series of more resistive thin beds $(10-200 \mathrm{~cm})$ alternating with relatively lower resistivity layers: a pattern that was manifested by alternating dark (low resistivity) and light (high resistivity) banding in the FMS images. We attribute this layering to interbedding of chert and porcellanite layers, a common lithologic sequence throughout Japan (Tada and lijima, 1983). Spatial frequency analysis of this interval of dominant dark-light banding showed spatial cycles of period of 1.1 to 1.3 and $0.6 \mathrm{~m}$. This pronounced layering and the correlation between the two sites terminate at $384 \mathrm{mbsf}$, coincident with the opal-CT to quartz transition at Site 794. We think the correlation in the FMS logs might well extend earlier in the middle Miocene, but the opal-CT to quartz transition obscures this layering below $384 \mathrm{mbsf}$.

Although $34 \mathrm{~m}$ is only a small part of the core recovered at these two sites, it is significant because it represents an area of extremely poor core recovery and an interval for which a near-depositional hiatus was postulated for Site 797, but not for Site 794.
\end{abstract}

\section{INTRODUCTION}

\section{What is the Formation Microscanner?}

The formation microscanner logging tool is a Schlumberger tool (Ekstrom et al., 1986; Boyeldieu and Jeffreys, 1988) designed to give a high-resolution image of the borehole wall through measurement of microresistivity. Microresistivity is measured with four pads placed firmly against the borehole wall, with each pad containing 16 microresistivity buttons (Boyeldieu and Jeffreys, 1988) and achieving resolution of $1 \mathrm{~cm}$. A diagram of one of these pads is provided as Figure 1 (taken from Taylor, Fujioka, et al., 1990).

In addition, the four FMS pads on the tool provide a four-armed caliper measurement plus detailed direction and inclination measurements. A schematic of the FMS tool is presented as Figure 2 (Taylor, Fujioka, et al., 1990). Even though the FMS tool was introduced in 1986, it was not used by ODP until Leg 126 (Pezard and Luthi, 1990; Taylor, Fujioka, et al., 1990) because a slim hole version of the tool was required for ODP use.

The FMS data are processed onshore by a Schlumberger service center. Here, the resolution of the data is increased, unwanted noise is filtered, and the logs are printed at a larger scale. In addition, resistivity balancing is applied to avoid oversaturation (completely white or completely dark intervals) of the images due to highly resistive nodules, and so forth.

Geologists have found the FMS tool useful for delineating fractures, dipping beds, thin beds, inclusions, or bioturbations (Ekstrom et al., 1986; Boyeldieu and Jeffreys, 1988; Bourke, 1989; Trouillier et al., 1989). Visual comparison of FMS images with core specimens has established the FMS as an important tool for describing the borehole environment.

\footnotetext{
'Tamaki, K., Suyehiro, K., Allan, J., McWilliams, M., et al., 1992. Proc. ODP, Sci. Results, 127/128, Pt. 2: College Station, TX (Ocean Drilling Program).

${ }^{2}$ Chevron Oil Field Research Co., 1300 Beach Blvd., La Habra, CA 90631, U.S.A.

${ }^{3}$ University of Tokyo, Geological Institute, 7-2-1 Hongo, Tokyo 113, Japan.
}

\section{Purpose of This Report}

The $34 \mathrm{~m}$ of correlation (350-384 mbsf) between the FMS logs taken at Sites 794 and 797 is only a small part of the sedimentary sequence in the Yamato Basin. Nonetheless, it is significant for the following reasons: (1) this interval represents an area of poor core recovery resulting from the difficulty in drilling through the alternating hard (chert) and soft (porcellanite) layers - the poorest core recovery in the sedimentary sequence; (2) this is an interval for which a near-depositional hiatus was postulated for Site $797(5 \mathrm{~m} / \mathrm{m} . \mathrm{y}$. deposition rate), but not Site 794 (35 m/m.y. deposition rate); and (3) on board the ship, two different gross lithology types were inferred for this interval (Tamaki, Pisciotto, Allan, et al., 1990).

The uniformity of the FMS logs between the two sites does not support either Conclusions 2 or 3 , reached after on-board analyses. The FMS logs do not support the concept of an isolated depositional hiatus in the Yamato Basin in the upper Miocene sediments or that two different lithologic units exist in this interval. The data do, however, support the reinterpretation of the lithologic and paleontologic data by Tada and Iijima (this volume) and Rahman (this volume).

Because the logs are qualitatively similar, we also tried to compare the logs quantitatively. The logs were sampled and correlation coefficients between sampled data of Sites 794 and 797 were taken. These correlation coefficients were not as large as the visual correlation might suggest. This is because small perturbations that are neglected during visual comparison degrade a correlation coefficient. However, cyclicity itself might be determined through the use of the cross spectrum, the spectrum of the cross-correlation of the sampled data from the two sites. When performing this analysis, a few spatial cycles were predominant, particularly one having a spatial period of 1.1 to $1.3 \mathrm{~m}$ and a lesser one having a spatial period of $0.6 \mathrm{~m}$. Given the overall deposition rates in the Yamato Basin at the time, this possibly may be the result of Milankovitch cyclicity.

\section{Shipboard Program-FMS Operations}

During Leg 127, the FMS tool string was run at the Yamato Basin, Sites 794 and 797, and at the Okushiri Ridge, Site 796. Because of 


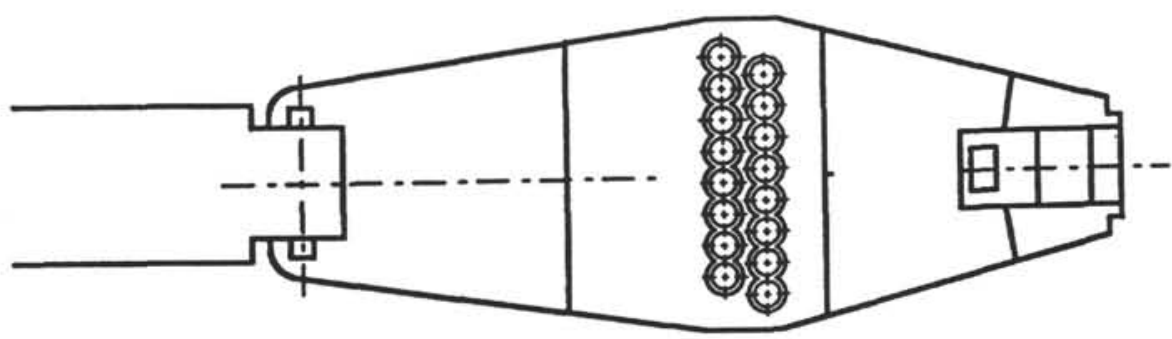

B

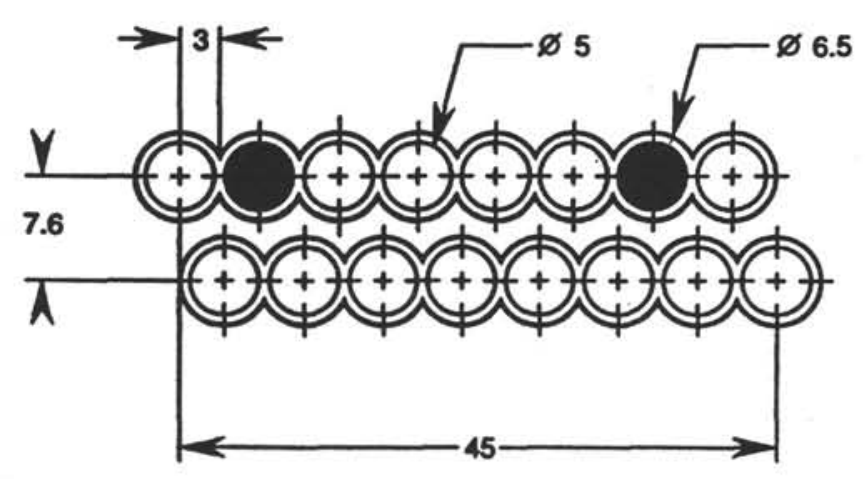

Figure 1. A. Diagram of one of four FMS pads on each tool used to measure microresistivity. B. The 16 buttons on each pad record data every $2.5 \mathrm{~mm}$. Dimensions are in millimeters (Lovell and Pezard, 1990, p. 41).

poor hole conditions, no FMS tool was run at Site 795, and at Site 796, no Miocene sediments were logged by the FMS.

At Site 794, the FMS tool was run in Hole 794B from 69 to 538 mbsf. At Site 797, the FMS tool was run in Hole 797C from 83 to 516 mbsf. In subsequent runs at Hole 797C, the FMS tool logged parts of basement deeper than $516 \mathrm{mbsf}$ and repeated parts of shallower sections. Because of severe changes in borehole diameter, no useful images could be obtained; however, useful basement FMS images from the Sea of Japan were obtained during Leg 128 (Ingle, Suyehiro, von Breymann, et al., 1990).

Therefore, the FMS program covered similar intervals in Holes $794 \mathrm{~B}$ and 797C, and one interval in particular (at 350 to $384 \mathrm{mbsf}$ ) was identified for comparison here.

\section{Shipboard Program-Core Recovery}

The extended core barrel (XCB) corer was used in Hole 794B to a depth of $350 \mathrm{mbsf}$ and in Hole 797B through a depth of $495 \mathrm{mbsf}$. The rotary core barrel (RCB) coring procedure was used in Hole 797C below 500 mbsf, but at Hole 794B, RCB coring began much shallower, below $350 \mathrm{mbsf}$.

Thus, over the interval between 350 and $384 \mathrm{mbsf}$, Hole 797B was cored with XCB coring and Hole 794B with RCB coring. Both holes had poor core recovery (Tamaki, Pisciotto, Allan, et al., 1990, p. 70) over this interval that ranged from retrieval of only core-catcher samples (Cores 127-794B-6R and -8R) to 20\% (Cores 127-797B$38 \mathrm{X},-40 \mathrm{X},-41 \mathrm{X})$ recovery. Figure 3 shows a graph of the core recovery at Sites 794 and 797 . Core recovery is better overall, but still poor with the XCB coring performed in Hole 797B.

Core recovery improved significantly below $384 \mathrm{mbsf}$ in Hole 794B, as shown in Figure 3. We think that this improvement can be explained by passing through the opal-CT to quartz transition zone at
$384 \mathrm{mbsf}$ and encountering rocks having less variable cementation. At Hole 797B, the core recovery did not improve until $420 \mathrm{mbsf}$, where the much deeper opal-CT to quartz transition zone was reached. Thus, although the opal-A to - CT transition zones occur at similar depths between the two sites, the opal-CT to quartz transition zones can be seen at distinctly different levels.

\section{Shipboard Program-Lithostratigraphic Interpretation}

A complete lithostratigraphic interpretation can be found in Tamaki, Pisciotto, Allan, et al. (1990). For the upper Miocene sediments, the interval from 350 to 384 mbsf was described as lithologic Subunit IIIB in Hole 794B, a claystone with a minor lithology of chert and porcellanite in discrete thin layers. In Hole $797 \mathrm{C}$, the same interval from 350 to $384 \mathrm{mbsf}$ was described as Subunit IVB, silty clay/claystone with no minor lithologies (Tamaki, Pisciotto, Allan, et al., 1990). However, Tada and Iijima (this volume) have compiled a revised lithostratigraphy that has an equivalent Subunit IVA at both sites in the 350- to 384-mbsf late Miocene interval. It is our opinion that the lithologies between the two sites in the 350 to 384 mbsf interval are equivalent and that the different lithostratigraphic description results from the limited core recovery and differences between RCB and XCB coring.

\section{DATA PROCESSING}

\section{Alignment by Depth}

When logging with different tool strings (as was done during Leg 127), one must align the various tool responses by depth. This quality control procedure is accomplished by using the natural gamma-ray tool (NGT) as part of each tool string (Tamaki, Pisciotto, Allan, et al., 1990 , p. 55-58). Then, this gamma-ray measurement can be correlated 


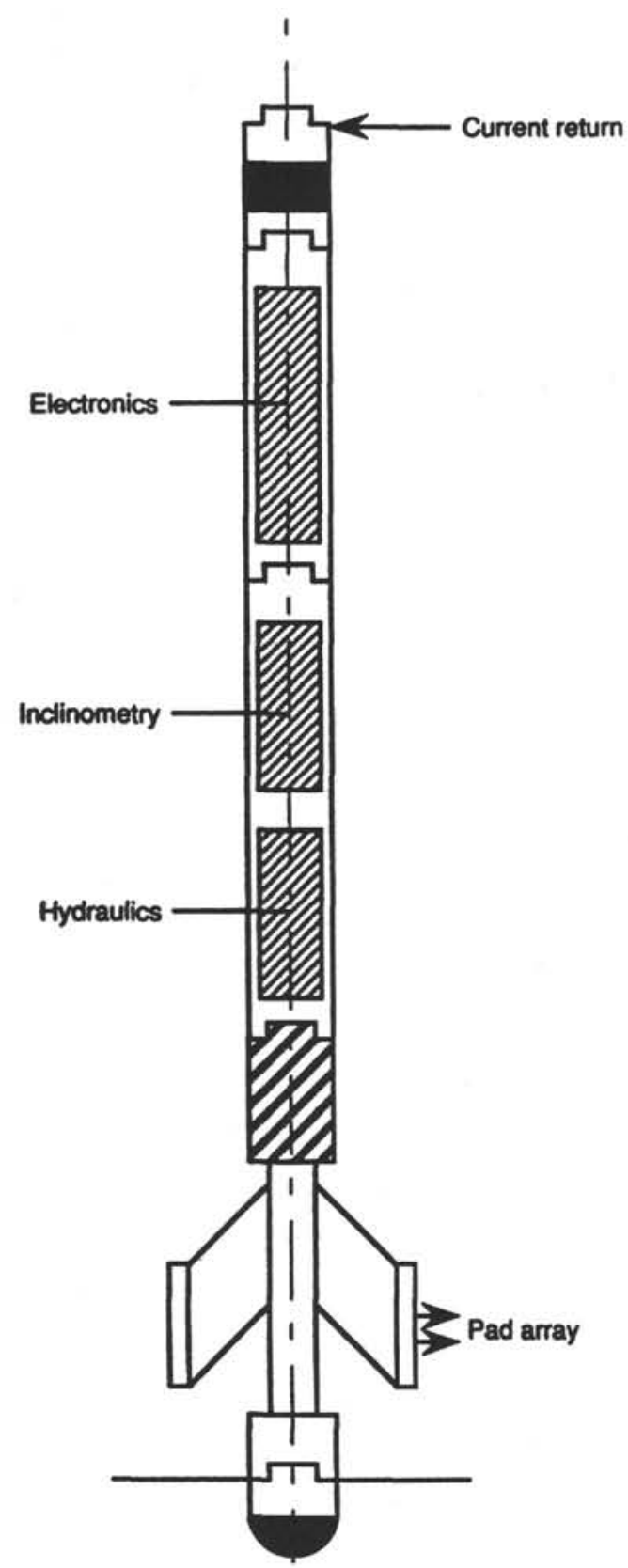

Figure 2. Diagram of the FMS tool showing how pads are arranged on the four-arm caliper (two pads are in the viewing plane). Also shown is the inclination cartridge for detailed geometry measurements and an electronics cartridge for transmitting data to the surface (Lovell and Pezard, 1990, p. 39).

among the various logging runs so that they agree on depth. Often this can be accomplished on board the ship, but at a shore-based laboratory, one of us (RT) noticed that this correlation was incorrect. We found that the FMS and resistivity logs were displaced by about $5.5 \mathrm{~m}$ in Hole $797 \mathrm{C}$ and $0.5 \mathrm{~m}$ in Hole 794B. The correct alignment in depth of the gamma-ray logs is displayed in Figure 4 for Hole 794B and in Figure 5 for Hole $797 \mathrm{C}$. The correct alignment in Figure 4 is readily apparent, but is much more subtle in Figure 5 for Hole $797 \mathrm{C}$. This subtlety for Hole $797 \mathrm{C}$ probably contributed to the $5.5-\mathrm{m}$ mismatch.
Hole 794B

Percent Core Recovery

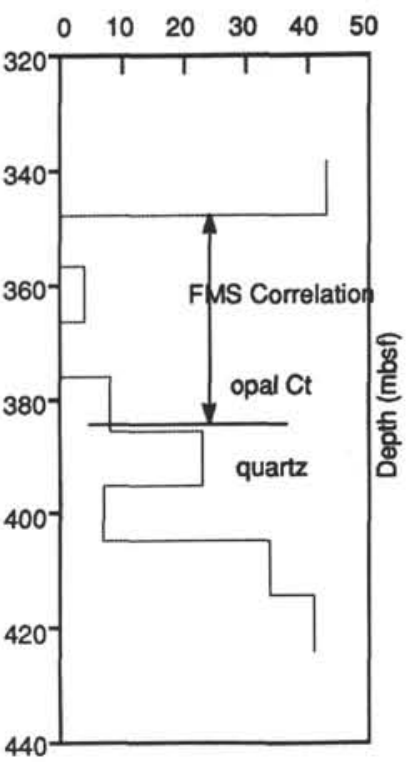

Hole 797C

Percent Core Recovery

$\begin{array}{llllll}0 & 10 & 20 & 30 & 40 & 50\end{array}$

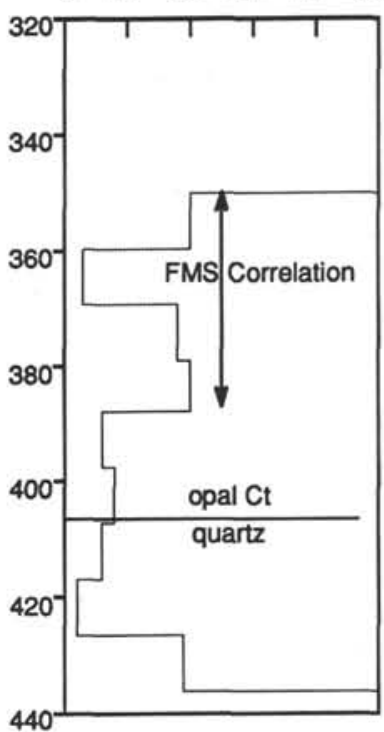

Figure 3. Comparison of percentage of core recovery, excluding the core catcher, at Holes 794B and 797C. Poor recovery in the zone of FMS correlation still occurs in the opal-CT zone at both sites. At $384 \mathrm{mbsf}$ in Hole 794B, the opal-CT to quartz transition takes place, and core recovery immediately increases. At Hole 797C, core recovery remains poor until the much deeper opal-CT to quartz transition is reached at $420 \mathrm{mbsf}$, when core recovery there rebounds, too. Many possible explanations for the retarded opal-CT to quartz transformation at Hole 797C come to mind (e.g., Tada, 1991).

After careful comparison of core depths with logging depths, we decided that the FMS depths were the most accurate. The correlation of core depths with FMS depths is presented in Table 1.

\section{Qualitative Comparison of FMS Logs from Sites 794 and 797}

What first led us to compare the FMS logs in the 350- to 384-mbsf interval was the similarity in the spherically focused resistivity log (SFL) between the two sites after alignment corrections presented in the last section. Figure 6 shows the resistivity logs of the two sites; the SFL log is the solid line in both plots. Clearly, the character of the two logs from 345 to 390 mbsf is similar.

Side-by-side display of the FMS logs from Holes 794B and 797C in the 350- to 384-mbsf interval shows the strong correlation between the two sites and is presented in Figures 7A through 7E. The depths of these correlations are presented in Table 2 and described below.

The first subinterval has been broken down into two images presented as Figures 7A and 7B. What we interpret as basinwide chert layers (the white bands) can be seen at 349.0, 351.5, and $352.3 \mathrm{mbsf}$ in the Hole $797 \mathrm{C}$ image and at 351.0, 353.0, 353.7 mbsf in the Hole 794B image (Fig. 7A). In Figure 7B, an especially thick cherty layer is seen at 356.0 mbsf in the Hole 794B image and at 354.9 mbsf in the Hole $797 \mathrm{C}$ image. Another convincing correlation is shown in Figure 7C, with the chert beds at 367.0 mbsf in the Hole 794B image and at $365.3 \mathrm{mbsf}$ in the Hole 797C image. In Figure 7D, chert intervals are recognized centered at $375.8,377.8$, and $378.8 \mathrm{mbsf}$ for Hole $794 \mathrm{~B}$ and at $374.8,376.8$, and $377.8 \mathrm{mbsf}$ for Hole $797 \mathrm{C}$ images. The visual correlation is still good, but is breaking down in Figure $7 \mathrm{E}$, where chert layers are recognized at 380.3 and 383.5 mbsf for Hole 794B images and at 379.7 and 382.9 mbsf for Hole $797 \mathrm{C}$ images. 
Hole 794B

Gamma Ray (API Units) FMS Tool String

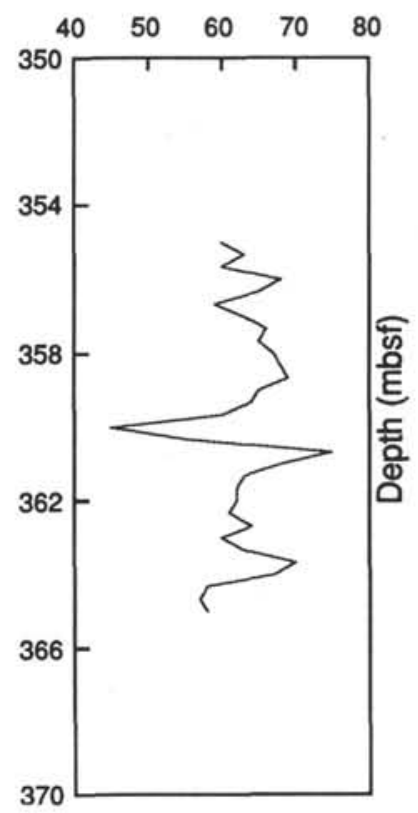

Hole 794B Gamma Ray (API Units) Sonic-Resistivity Tool String $\begin{array}{lllll}40 & 50 & 60 & 70 & 80\end{array}$

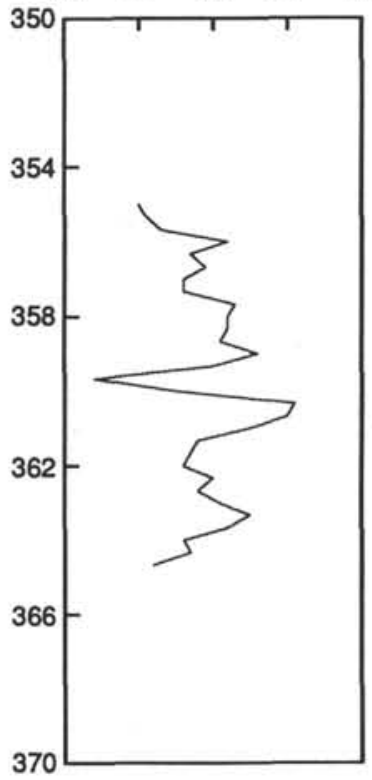

Figure 4. Correlation of the SGR log from the natural gamma-ray tool placed on the sonic-resistivity tool string with the FMS tool string for Hole 794B. This demonstrates a $0.5-\mathrm{m}$ discrepancy between measurements for Hole 794B. We postulate that true depth is that of the FMS tool string because of its correlation with the core at key interfaces (see Table 2).

Besides the visual correlation seen in the side-by-side comparison of the FMS logs, it is also interesting to note how closely these intervals from the two sites correspond in true depth. These intervals vary at most by $2 \mathrm{~m}$ in true depth, although they are roughly $360 \mathrm{~km}$ apart!

It is our opinion that the correlation at the two sites is obscured below $384 \mathrm{mbsf}$ by passage through the opal-CT to quartz transition zone at Hole 794B, which produced large physical and chemical changes (Tada and Iijima, 1983; Tada, 1991). Evidence for the large changes in properties can be viewed by looking at side-by-side comparisons of the SFL log (presented in Fig. 6). As is obvious from Figure 6, resistivity fluctuates with large amplitude within the opalCT zone in both holes, whereas the amplitude of the resistivity and the spikiness is reduced once the opal-CT to quartz transition occurs at $384 \mathrm{mbsf}$ in Hole 794B. A corresponding decrease for Hole 797C is not seen until 420 mbsf. The largest resistivities for both holes are seen in the chert layers, the spikes, above the opal-CT to quartz transition. This deamplification in resistivity corresponding to opalCT to quartz transformation is probably the result of drastic change in pore structure (Tada and Iijima, 1983) and conversion of structural water in chert to free water in quartzose rocks (Tada et al., 1987).

\section{Signal Processing}

The chief result of this study is the identification of a visual correlation of the FMS images from Hole 794B with those from Hole 797C for selected depth intervals in the late Miocene sequence. We attempted to define this correlation in a more quantitative manner through the use of statistical and signal processing; the results are presented in this section.

The procedure was first to assume all white layers in the FMS images were representative of chert and make all black intervals representative of porcellanite. The chert layers were assigned a value of 1 and the porcellanite layers a value of 0 . The FMS images from
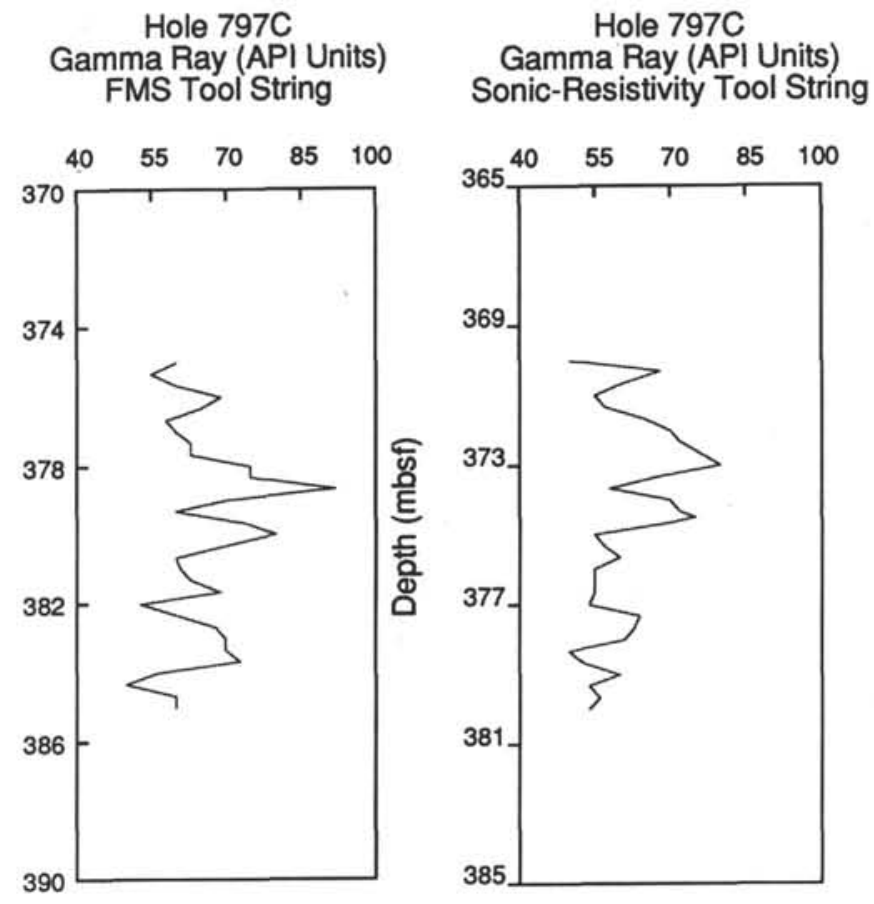

Figure 5. Correlation of the SGR log from the natural gamma-ray tool placed on the sonic-resistivity tool string with the FMS tool string for Hole 797C. Correlation is not nearly as good as that shown in Figure 4, but is still evident. This demonstrates a 5.5-m discrepancy between the measurements for Hole 797C. We think that true depth is that of the FMS tool string because of its correlation with the core at key interfaces (see Table 2).

Holes 794B and 797C were sampled at $10-\mathrm{cm}$ intervals from 350 to $384 \mathrm{mbsf}$ after this was determined. Two assumptions were made in the sampling: (1) beds were under $10 \mathrm{~cm}$ and were not resolvable from the images and (2) that the sedimentation rates between the two sites were equivalent based on the correlation.

\section{Signal Processing—Correlation Coefficient}

The first technique used is that of calculating the correlation coefficient, $r$, for the intervals identified in Table 1. A correlation coefficient is a number between -1 and 1 , with 0 indicating no correlation, +1 perfect positive correlation, and -1 perfect negative correlation. The correlation coefficients between the two holes for the various intervals are presented in Table 3 , with the first interval having been partitioned because of its great length. The correlation is unmistakable visually (Figs. 7A through 7E), and these correlation coefficients support this result, although not as strongly as the visual

Table 1. Correlation of core depths with log depths for key diagenetic horizons.

\begin{tabular}{lcccc}
\hline Hole & Boundary & $\begin{array}{c}\text { Core depth } \\
(\mathrm{m})\end{array}$ & $\begin{array}{c}\text { FMS depth } \\
(\mathrm{m})\end{array}$ & $\begin{array}{c}\text { Sonic-resistivity } \\
\text { depth } \\
(\mathrm{m})\end{array}$ \\
\hline 794B & A to CT & $296-303$ & $289.5-295.5$ & $290.0-296.0$ \\
794B & CT to Qtz & $386-396$ & 395.0 & 394.5 \\
797B & A to CT & $299-306$ & $303.5-305.5$ & $298.0-300.0$ \\
797C & A to CT & & 427.5 & 424 \\
797C & CT to Qtz & $428-438$ & & \\
\hline
\end{tabular}

Note: One can see that the sonic-resistivity and FMS logs agree closely in depth for Hole 794B, but are offset by about 4 to $5 \mathrm{~m}$ in Hole 797C. FMS value is thought to be the correct depth for Hole 797C. 
Hole 794B

Resistivity Logs

SFL - Solid Line

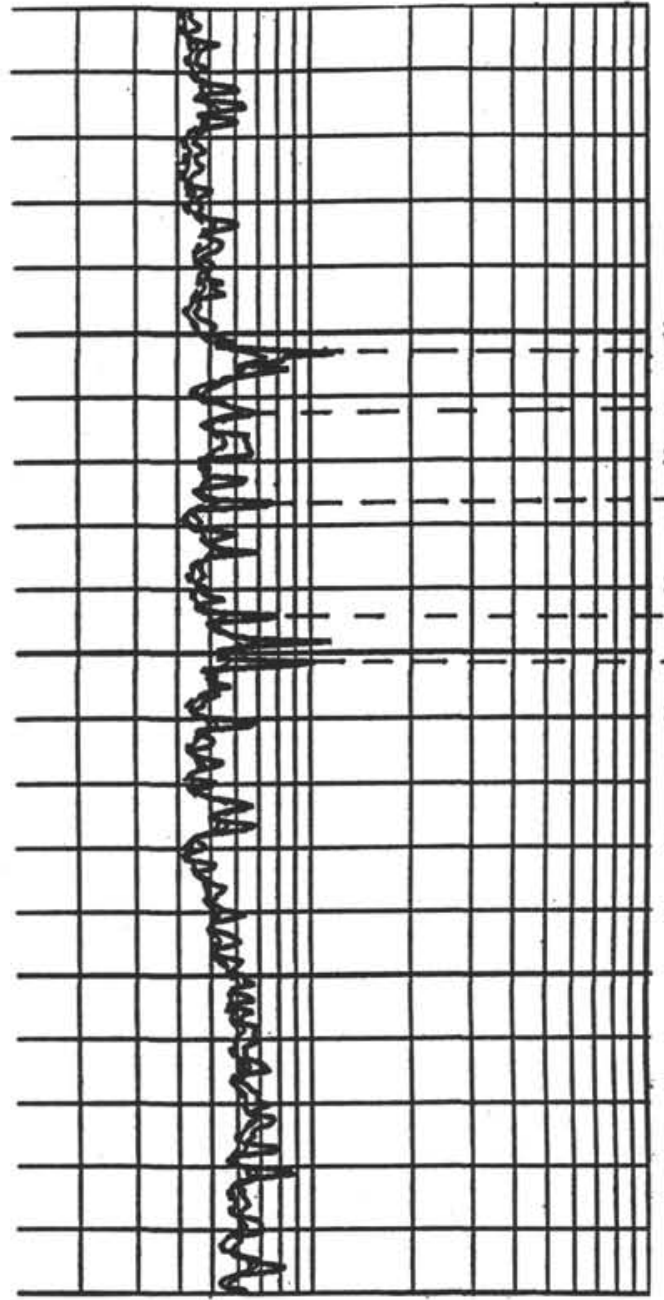

Hole 797C

Resistivity Logs

SFL - Solid Line

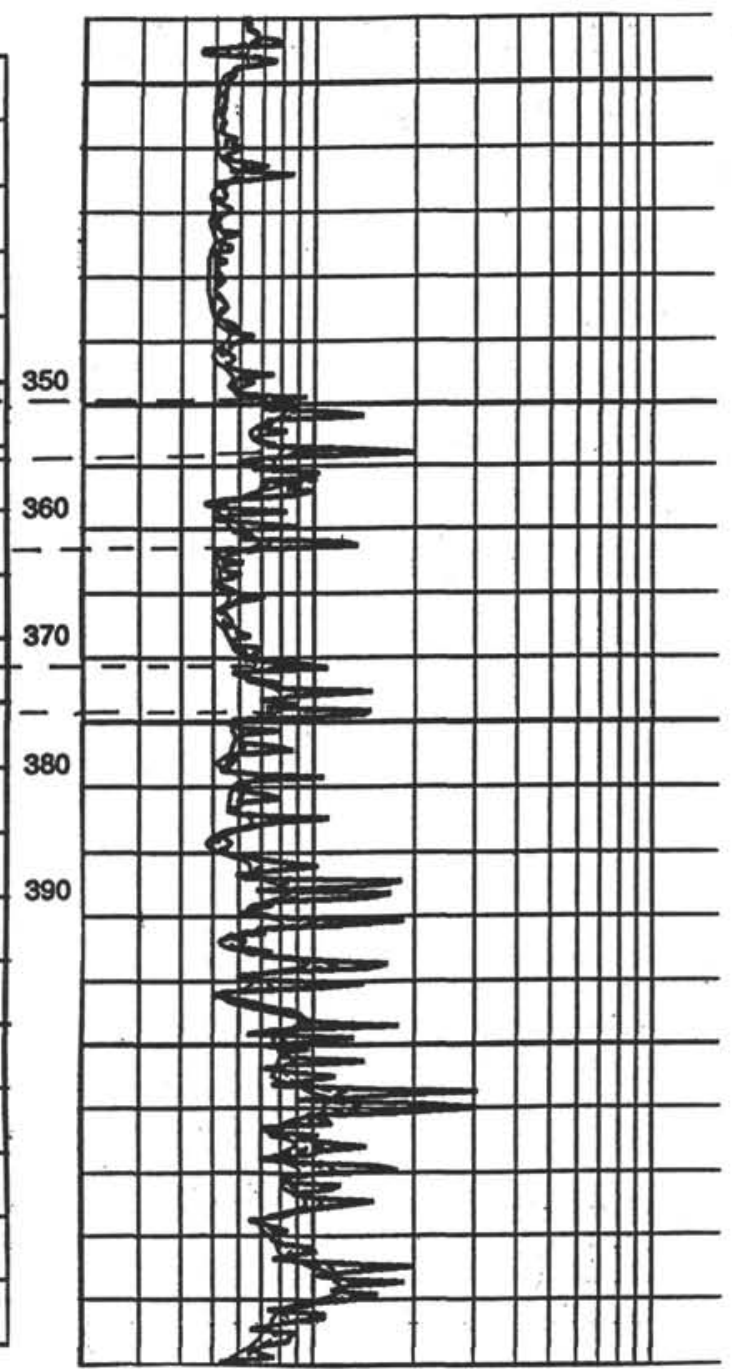

Figure 6. Correlation of the resistivity logs of Hole 794B with those of Hole 797C. The spherically focused $\log$ reading is the solid line, and the logarithmic resistivity scale is from 0.2 to $20 \mathrm{ohm}-\mathrm{m}$. The SFL reading measures the resistivity closest to the borehole. One can see that many of the SFL peaks and troughs are aligned in the interval between 350 and 384 mbsf, some of which are denoted by dashed lines.

correlation might indicate. Some difficulty is seen when calculating the correlation coefficient because of slightly differing deposition rates, causing misalignment in the images, but this was to be expected. In Figure 7E, for example, we show a good visual correlation, but only a 0.17 correlation coefficient. Correlation coefficients run over other sections showed zero correlation. Given that these sites are approximately $360 \mathrm{~km}$ apart and were drilled by two different coring techniques, even the correlation to this degree is surprising.

An observation from studying the FMS images is that there seems to be a cyclicity in the image data that correlates between the two sites. In other words, the pattern of highly resistive chert layers seems to replicate itself with depth. One way of comparing the two data sets for quantifying this observation is to use the common signal processing techniques of cross correlation and Fourier analysis.

\section{Signal Processing-Cross Correlation and Cross Spectrum}

In principle, cross correlation (i.e., Bracewell, 1986) is the calculation of a shifted correlation coefficient. As the two depth series are shifted past each other, the values are multiplied vs. each other data point by data point. Symbolically, the cross correlation of two series $x(i), y(i)$ is given by

$$
x \times y
$$

and mathematically, the cross correlation process of two depth series is given by the following formula, 
794B

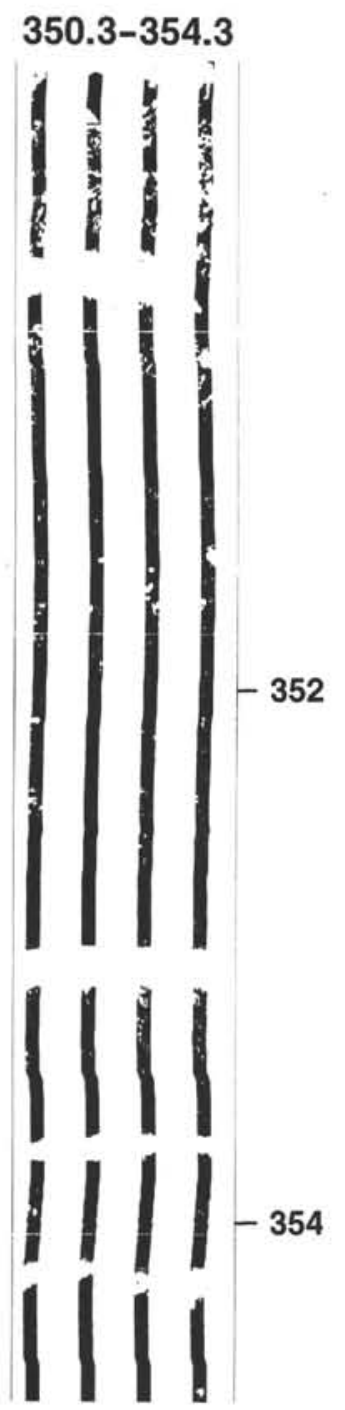

$797 \mathrm{C}$

348.5-353.2

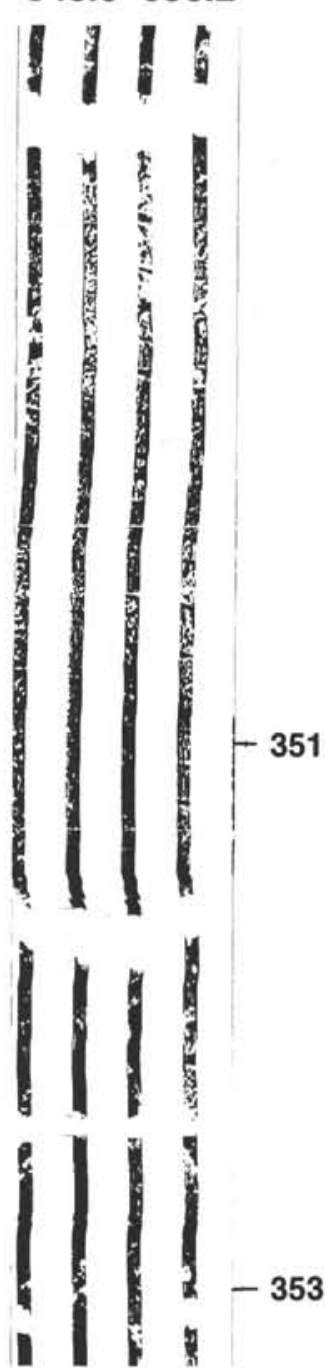

794B

353.8-357.1

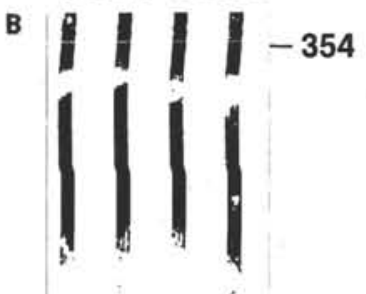

1 1

111

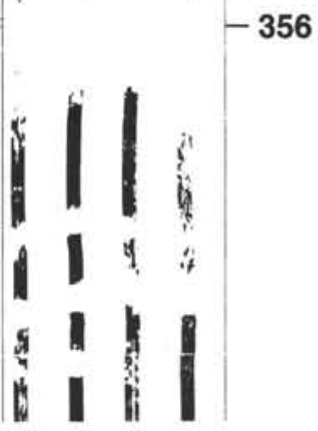

$797 C$

352.7-355.8

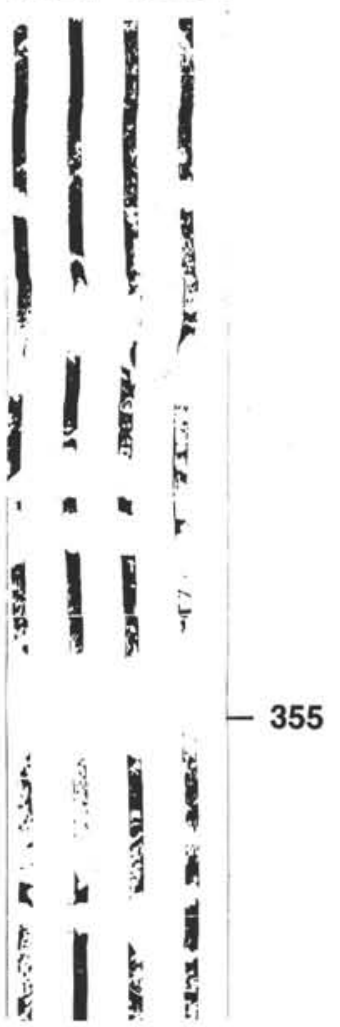

Figure 7. A. Visual correlation of FMS images for Holes 797C and 794B (intervals 350.3-354.3 at Hole 794B and 348.5-353.2 at Hole 797C). B. Visual correlation of FMS images for Holes 797C and 794B (intervals 353.8-357.1 at Hole 794B and 352.7-355.8 at Hole 797C). C. Visual correlation of FMS images for Holes 797C and 794B (intervals 366.3-370.8 at Hole 794B and 365-369.6 at Hole 797C. D. Visual correlation of FMS images for Holes 797C and 794B (intervals 375.5-379.5 at Hole 794B and 374.5-378.5 at Hole 797C). E. Visual correlation of FMS images for Holes 797C and 794B (intervals 380.1-384.2 at Hole 794B and $379.5-383.5$ at Hole 797C).

$$
x(i) \times y(i)=\sum x(t+i) y(t) .
$$

In our case, $x$ indicates the depth series from Hole 794B and $y$ the depth series from Hole 797C.

What the cross correlation process gives us is an indication of similarity. Peaks in the cross correlation are indicative of local correlation. By measuring the distances between these peaks, a qualitative indication of the underlying periodicity should be evident. By taking the Fourier transform of the cross correlation, we obtain the cross spectrum. The cross correlation of the two depth series of sampled FMS data was performed, and the result is presented as Figure 8 . The depth axis is the sum of the length of the two series, which is $34 \mathrm{~m} \times$ 2 , or $68 \mathrm{~m}$.

Figure 8 shows numerous spikes, indicating that shifting the image data by small amounts can produce large changes in the correlation between the two holes. It is possible to discern some controlling behavior from these graphs. In particular, a 1.1- to 1.3-m replication of spikes is apparent throughout the graph, along with much lower frequency behavior. Seemingly, other intervals exist, but this one stands out as a strong signal.

The cross spectrum, or more specifically the spatial spectrum of the cross correlation (Fig. 9), supports this observation. A signal clearly stands out from the background between 0.8 and 0.9 cycles $/ \mathrm{m}$. This signal corresponds to a spatial period of 1.1 to $1.3 \mathrm{~m}$. Another possible signal is seen at 1.7 cycles $/ \mathrm{m}$, which corresponds to a $0.6-\mathrm{m}$ spatial period. Figure 9 supports (in a quantitative manner) the visual observation from Figure 8 of a 1.1- to 1.3-m period between the spikes dominating the cross correlation. Hence, it is an important figure that indicates that a spatial periodicity of 1.1 to $1.3 \mathrm{~m}$ is evident in the sedimentation rate for these two sites. 


\section{B}

\section{3-370.8}

C

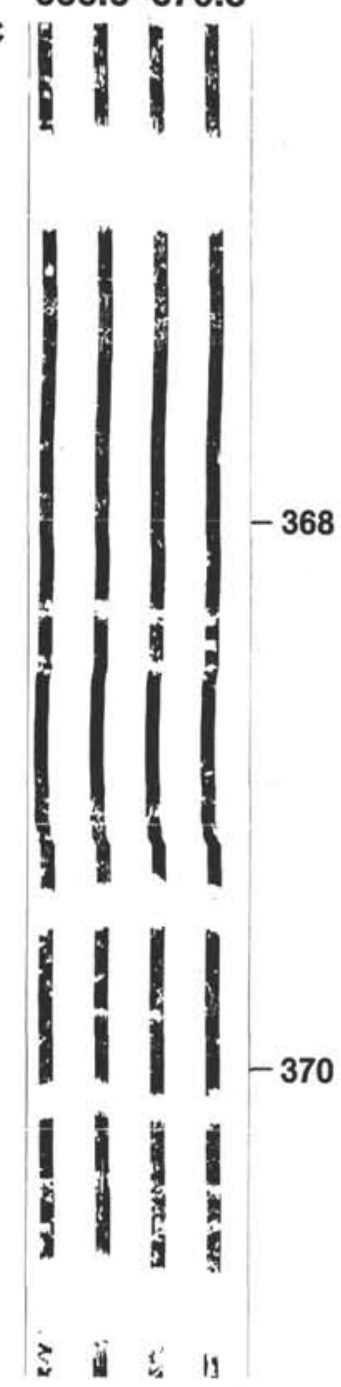

$797 \mathrm{C}$

365.0-369.6

11

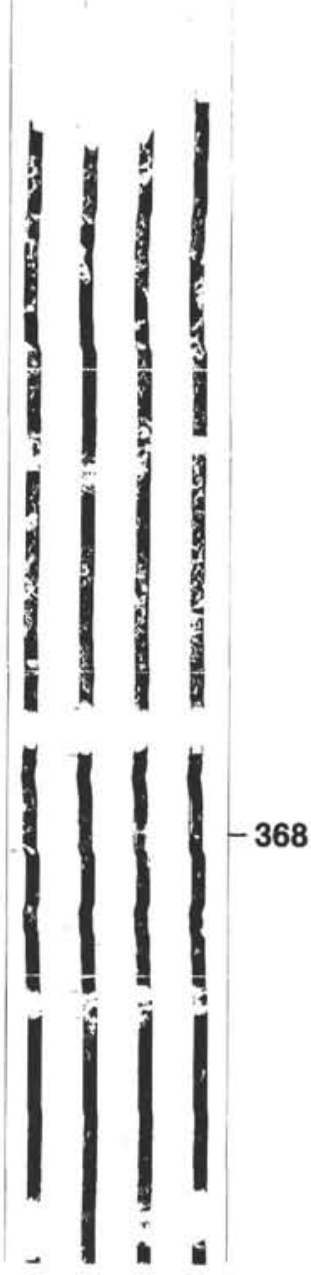

Figure 7 (continued).

\section{Signal Processing—Fourier Transforms}

Fourier transforms were also applied to the individually sampled FMS data before cross correlation, and the two transforms are shown side by side in Figure 10. In general, it is obvious that the two Fourier transforms share a similar structure. For instance, both fall off in amplitude above 1.7 cycles $/ \mathrm{m}$, and both have similar magnitudes, which perhaps indicates grossly the same amount of chert layer deposition at the two sites. However, it is hard to compare the two results directly spatial frequency by spatial frequency because small perturbations in the deposition rate would lead to large changes in the spatial frequencies used to reconstruct them.

\section{CYCLICITY}

The 1.1- to 1.3-m spatial signal and 0.6-m spatial signal in the cross correlation, supported by its spectrum, the cross spectrum, can be interpreted in terms of chronostratigraphy. Interpreting these sig-

794B

\section{5-379.5}

D

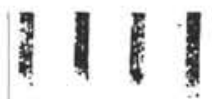

$-378$

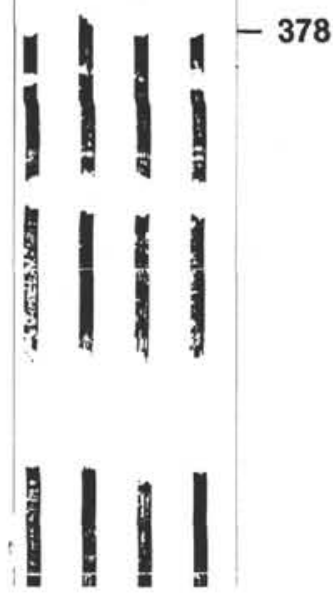

$797 \mathrm{C}$

374.5-378.5

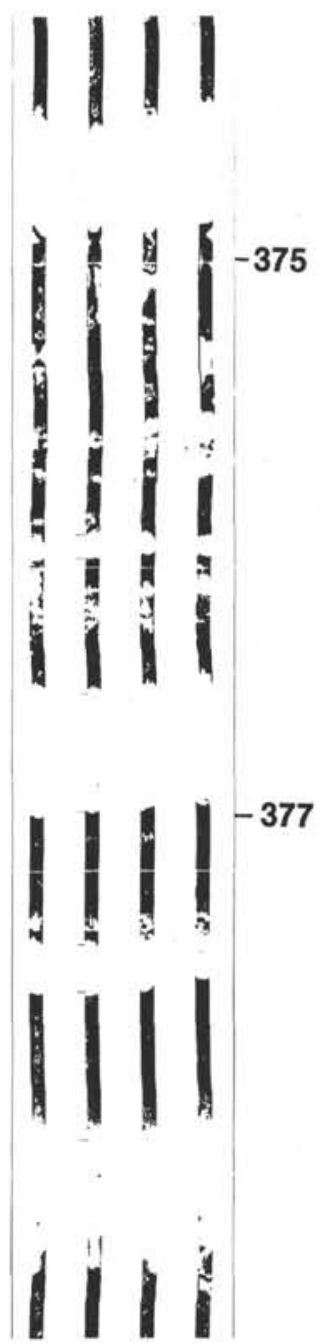

nals in terms of shipboard depositional rate data is problematic. Deposition rates at the two sites were given as $5 \mathrm{~m} / \mathrm{m}$.y. for Site 797 and $37 \mathrm{~m} / \mathrm{m}$.y. at Site 794 (Tamaki, Pisciotto, Allan, et al., 1990, pp. $112,366)$ based on nannofossil control, which indicates a substantial discrepancy.

Based on the correlation in the late Miocene section of the FMS logs, a more similar depositional rate would be supported. Re-evaluation of biostratigraphic data suggests large uncertainty in the age of the sediments below the opal-A to -CT boundary. Additional nannofossil data by Rahman (this volume) suggest a sedimentation rate of 20 to $60 \mathrm{~m} / \mathrm{m}$.y. for these intervals at both sites. For the sake of argument, we will assume a deposition rate of $27 \mathrm{~m} / \mathrm{m}$.y. Given this figure, the 1.1 - to $1.3-\mathrm{m}$ cycle might correspond to a 41,000 - to 48,000 -yr period and the 0.6 -m cycle might correspond to a 22,000 yr period. These cycles are near the values for the Milankovitch obliquity cycle $(41,000 \mathrm{yr})$ and the orbital precession cycle $(19,000$ $21,0000 \mathrm{yr}$ ). The small length of the depth series (of only $34 \mathrm{~m}$ ) would preclude accurate analysis of periods of longer cycles. 
794B

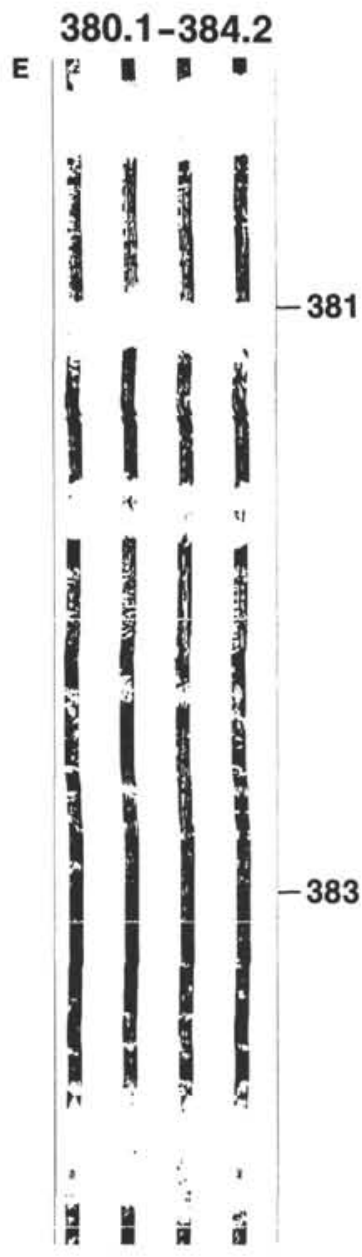

$797 \mathrm{C}$

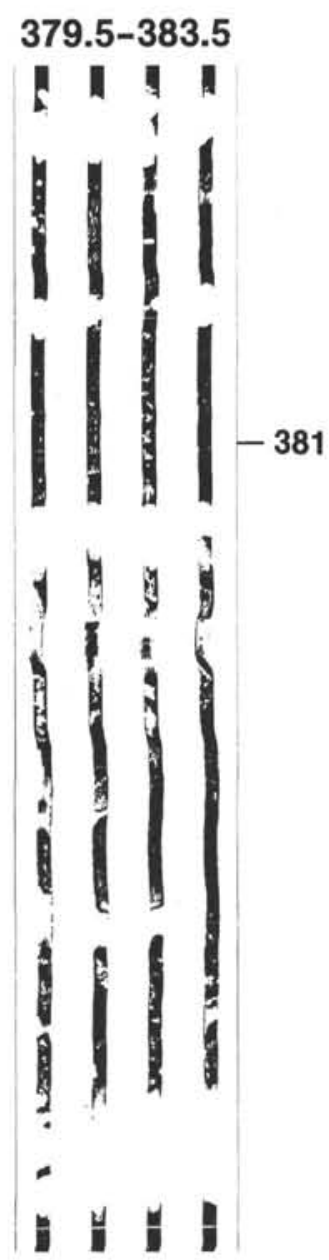

Figure 7 (continued).

\section{CONCLUSIONS}

We have shown the strong qualitative agreement between the FMS images acquired at Sites 794 and 797 from depths of 350 to 384 mbsf before the opal-CT to quartz transition zone in Site 794. The character of interbedded highly resistive (which we infer to be chert) and less resistive layers (which we infer to be porcellanite) continues in Site 797 to the opal-CT to quartz transition zone at 420 mbsf.

The implications of this agreement are two-fold and contradict some conclusions reached from shipboard data, based on the poor amount of core recovered in the interval. First, the two units at this depth are lithologically equivalent, as hypothesized by Tada and lijima (this volume) and, second, deposition rates of $5 \mathrm{~m} / \mathrm{m}$.y. for Site 797 and $35 \mathrm{~m} / \mathrm{m}$.y. for Site 794 are hard to reconcile with these data. Therefore, these results would instead support the reinterpretation of nannofossil data by Rahman (this volume).

On a quantitative basis, we have demonstrated positive correlation between the highly resistive chert layers at the two sites. Calculation of the cross spectrum of the FMS images in the 350- to 384-mbsf interval show a definite cycle of 1.1 - to $1.3-\mathrm{m}$ period and a weaker one of $0.6-\mathrm{m}$ period. These cycles might correspond to Milankovitch

Table 2. Intervals of correlation between Holes 794B and 797C.

\begin{tabular}{cc}
\hline $\begin{array}{c}\text { Interval Hole 794B } \\
(\mathrm{m})\end{array}$ & $\begin{array}{c}\text { Interval Hole 797C } \\
(\mathrm{m})\end{array}$ \\
\hline $350.3-357.1$ & $348.5-355.8$ \\
$366.3-370.8$ & $365.0-369.6$ \\
$375.2-379.9$ & $374.3-379.0$ \\
$380.1-384.2$ & $379.5-383.5$ \\
\hline
\end{tabular}

periods, if a $27-\mathrm{m} / \mathrm{m}$.y. deposition rate is assumed, although no definitive proof exists from these data that this is in fact the deposition rate.

The FMS log has potential as both a qualitative and quantitative analysis tool for ODP. Where core recovery is poor, the FMS should be looked at closely as a tool to assist in efforts of unit identification and correlation.

\section{ACKNOWLEDGMENTS}

We thank the crew of Leg 127 for assisting with collection of FMS data, and particularly Devon Dartnell, Schlumberger Engineer, for obtaining high-quality FMS images. Robin Reynolds at Lamont-Doherty's Borehole Research Group cataloged the data and helped supervise Leonard Troches of Schlumberger when doing the final processing. In the production of this paper, we thank the Administrative Services section of Chevron Oil Field Research Co.

\section{REFERENCES}

Bourke, L.T., 1989. Recognizing artifact images of the formation microscanner. SPWLA 30th Annu. Logging Symp., Pap. WW.

Boyeldieu, C., and Jeffreys, P., 1988. Formation microscanner: new developments. SPWLA Europ. Formation Eval. Symp., Pap. WW.

Bracewell, R.N., 1986. The Fourier Transform and Its Applications: New York (McGraw-Hill).

Ekstrom, M.P., Dahan, C.A., Chen, M.Y., Lloyd, P.M., and Rossi, D.J., 1986. Formation imaging with microelectrical scanning arrays. SPWLA 27th Annu. Logging Symp., 1-21.

Ingle, J.C., Jr., Suyehiro, K., von Breymann, M.T., et al., 1990. Proc. ODP, Init. Repts., 128: College Station, TX (Ocean Drilling Program).

Lovell, M., and Pezard, M., 1990. In Taylor, B., Fujioka, K., et al., Proc. ODP, Init. Repts., 128: College Station, TX (Ocean Drilling Program), 39-41.

Pezard, P., and Lovell, M., 1990. Downhole images: electrical scanning reveals the nature of subsurface oceanic crust. Eos, 71:1384-1393.

Pezard, P., and Luthi, S., 1988. Borehole electrical images in the basement of the Cajon Pass scientific drill hole, California: fracture identification and tectonic implications, Geophys. Res. Lett., 15:1017.

Tada, R., 1991. Compaction and cementation in siliceous rocks and their possible effect on bedding enhancement. In Einsele, G., Ricken, W., and Seilacher, A. (Eds.), Cycles and Events in Stratigraphy: New York (Springer-Verlag).

Tada, R., and lijima, A., 1983. Petrology and diagenetic changes of Neogene siliceous rocks in northern Japan. J. Sediment. Petrol., 53:911-930.

Tada, R., Maliva, R., and Siever, R., 1987. A new mechanism for pressure solution in porous quartzose sandstones. Geochim. Cosmochim. Acta, 51:2295-2301.

Tamaki, K., Pisciotto, K., Allan, J., et al., 1990. Proc. ODP, Init. Repts., 127: College Station, TX (Ocean Drilling Program).

Taylor, B., Fujioka, K., et al., 1990. Proc. ODP, Init. Repts., 126: College Station, TX (Ocean Drilling Program).

Trouiller, J.C., Delhomme, JP., Carlin, S., and Anxionnaz, H., 1989. Thin-bed reservoir analysis from borehole electrical images. Paper presented at the Soc. Pet. Engrs, 64th Annu. Fall Meeting.

Date of initial receipt: 20 March 1991

Date of acceptance: 2 December 1991

Ms 127/128B-224 


\section{Crosscorrelation of sampled FMS data from Holes 794B and 797C, 350-384 mbsf}

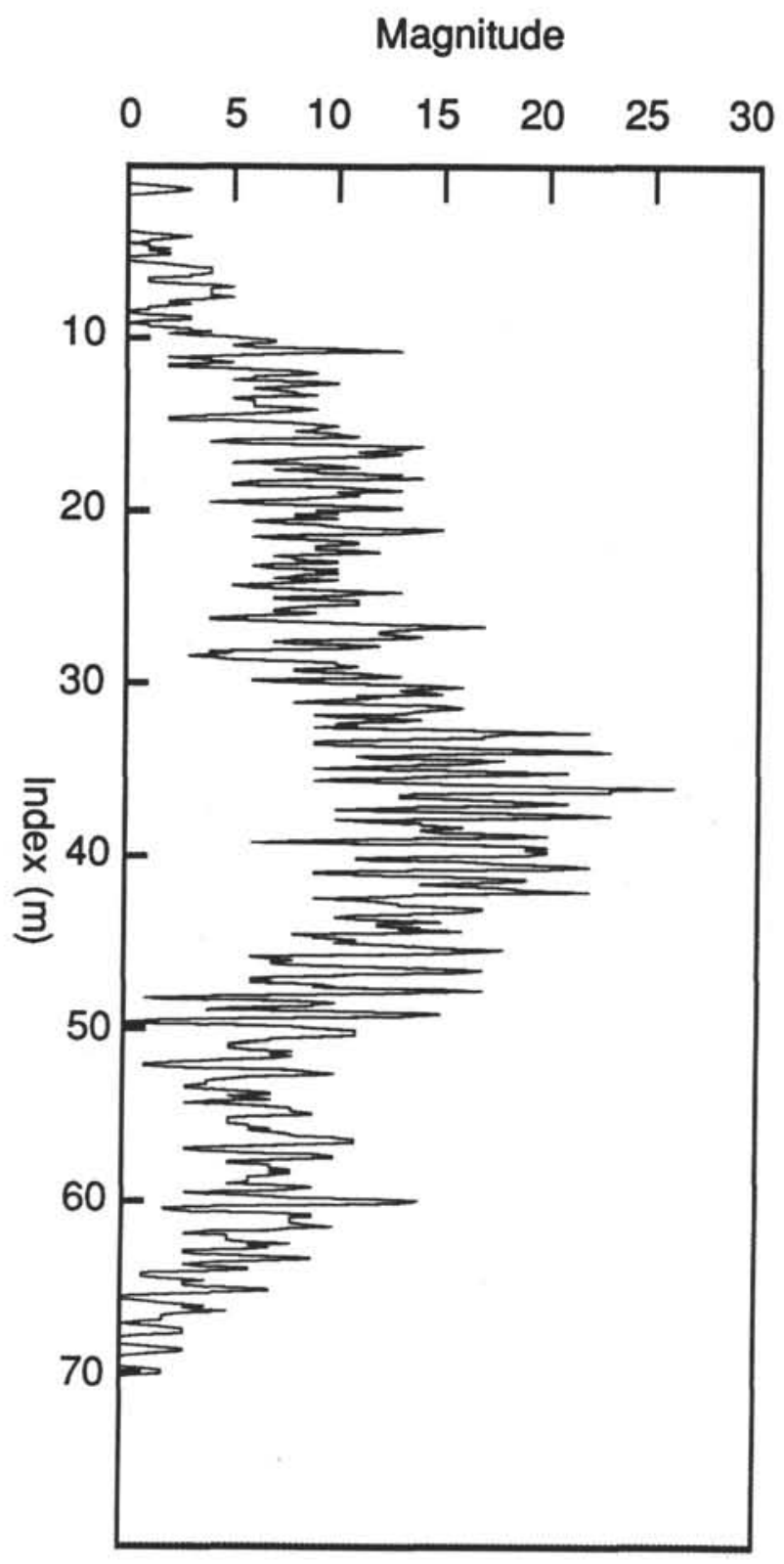

Figure 8. Cross correlation of two depth series from Holes 794B and 797C. The clearest feature are the spikes, which seem to have an underlining period. The peak correlation reached by these spikes is about one-half that of the possible correlation seen at the midpoint of the graph. Other cycles are evident, but not as clear as the 1.2-to 1.3-m cycle. The $y$-axis is meters of shift between the two series, with the top representing $-34 \mathrm{~m}$ and the bottom, $+34 \mathrm{~m}$.

\section{Fourier Transform of Cross Correlation of sampled FMS data, Holes 794B and 797C}

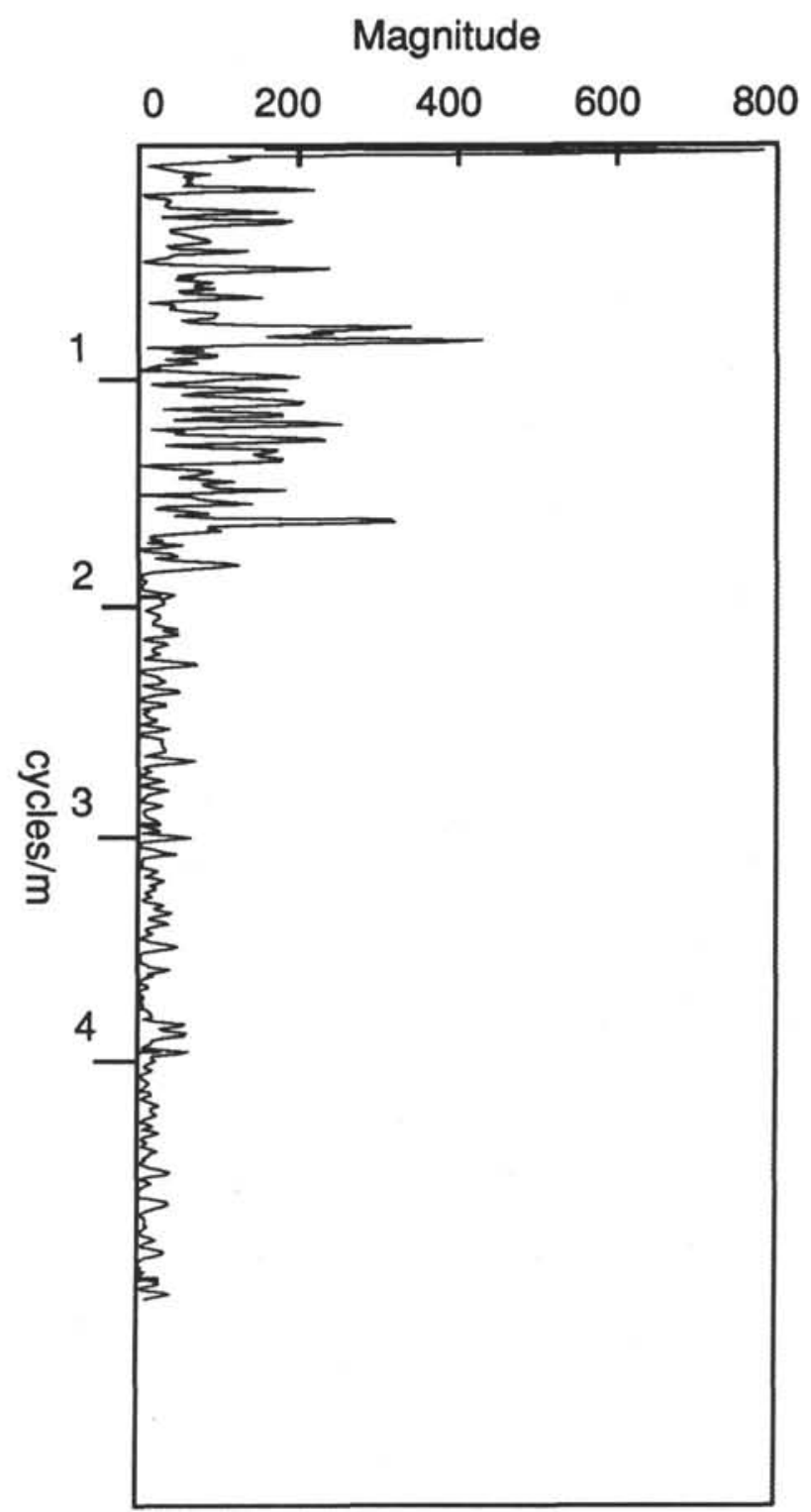

Figure 9. Spectrum of the cross correlation of two depth series from Holes $794 \mathrm{~B}$ and $797 \mathrm{C}$, the cross spectrum. Here, the most evident feature is the increased amplitude from 0.8 to $0.9 \mathrm{cycles} / \mathrm{m}$, which correspond to the 1.1 - to 1.3-m cycles (noticed in Fig. 8). Another spike at about $1.7 \mathrm{~m}$ also stands out, 
Fourier Transform of sampled FMS data, Hole 794B

Magnitude

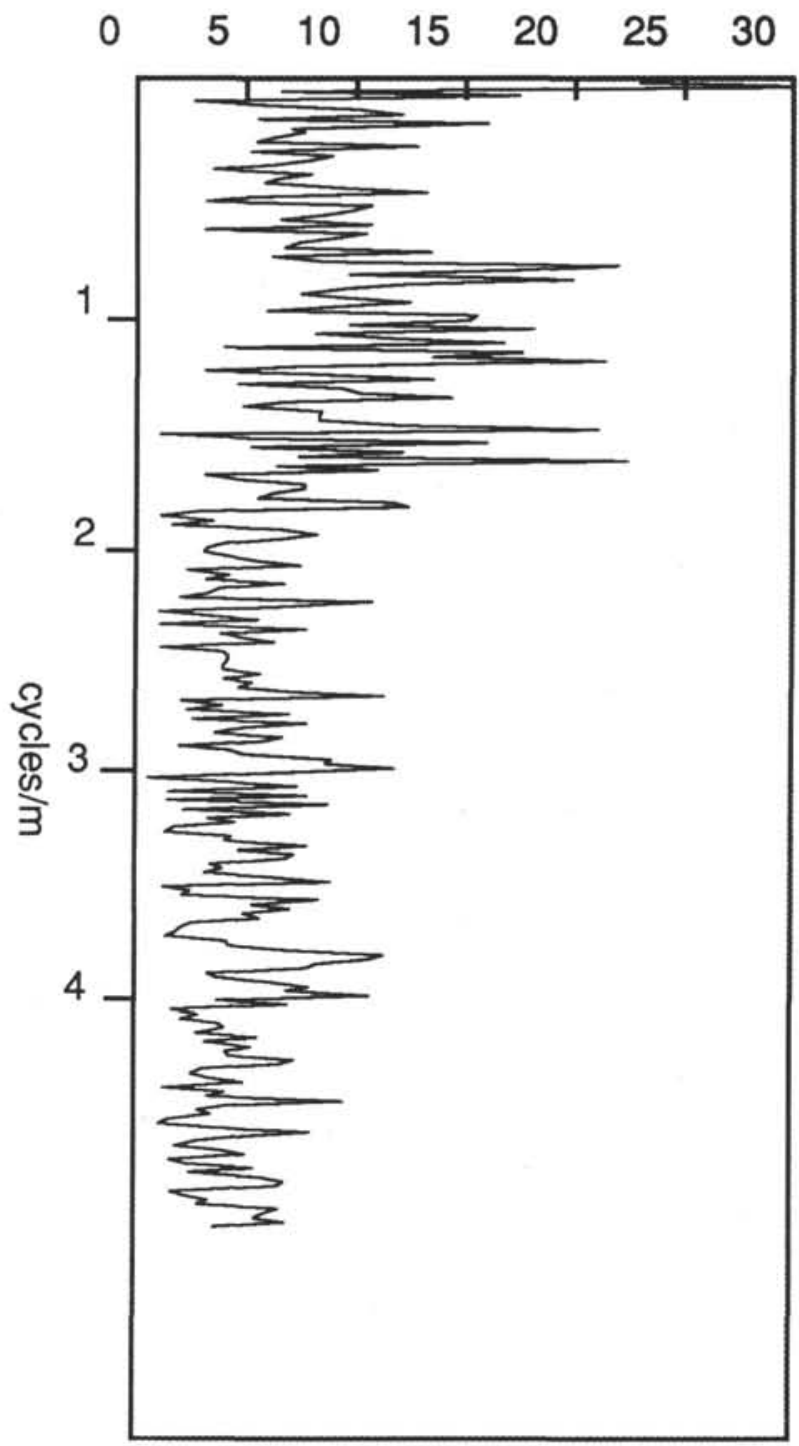

Fourier Transform of sampled FMS data, Hole 797C

Magnitude

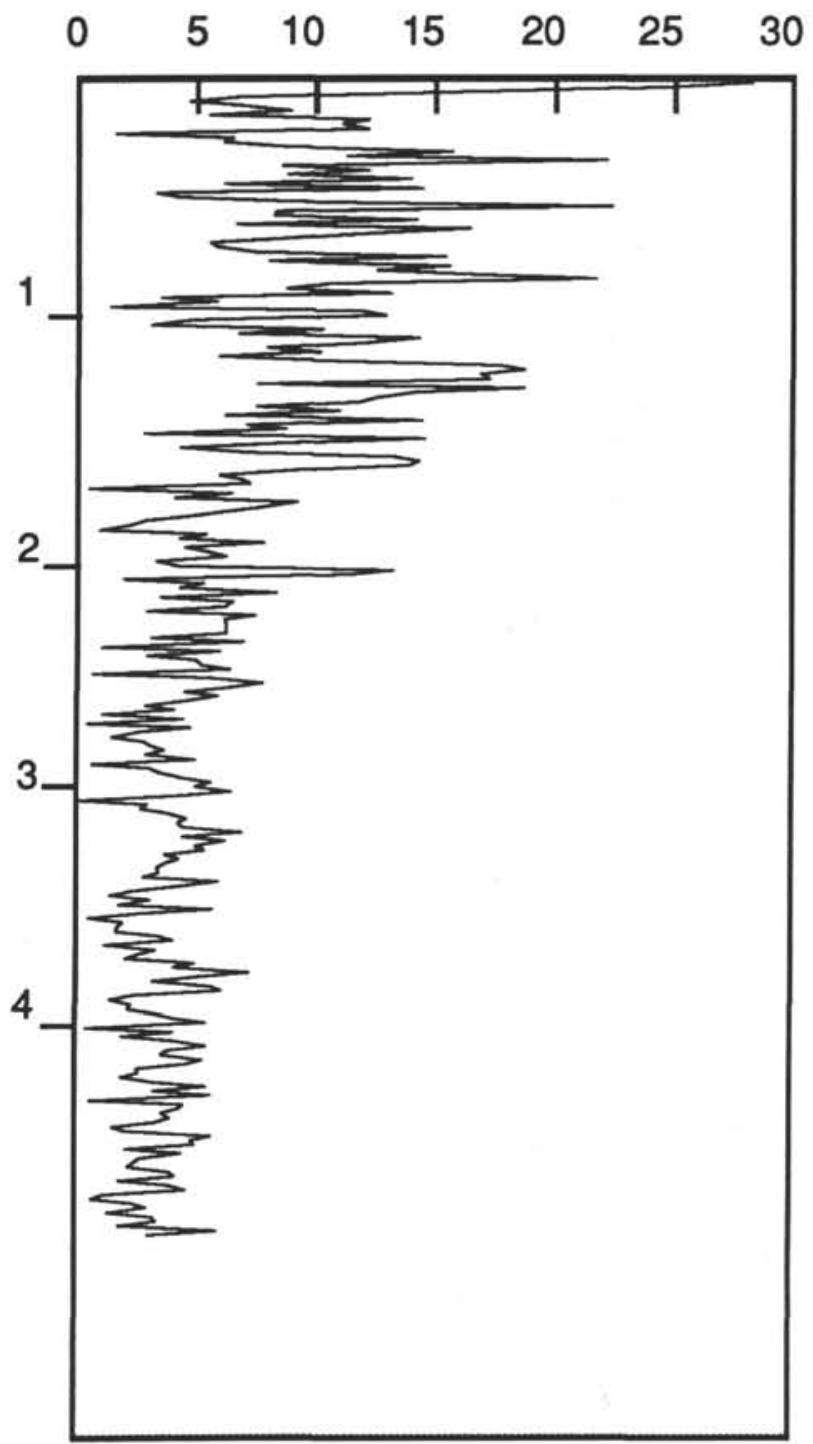

Figure 10. Fourier transform of sampled FMS data from 350 to $384 \mathrm{mbsf}$ in Holes 794B and 797C. The general character of the two spectra is similar, but small perturbations in deposition rate prevent the two from being more nearly identical.

Table 3. Correlation coefficients for selected intervals.

\begin{tabular}{crc}
\hline $\begin{array}{c}\text { Interval in } \\
\text { Hole 794B } \\
(\mathrm{m})\end{array}$ & $\begin{array}{c}\text { Interval in } \\
\text { Hole 797C } \\
(\mathrm{m})\end{array}$ & $\begin{array}{c}\text { Correlation } \\
\text { coefficient, } \\
r\end{array}$ \\
\hline $350.3-354.3$ & $348.5-353.2$ & 0.20 \\
$353.8-357.1$ & $352.7 .5-355.8$ & 0.34 \\
$366.3-370.8$ & $365.0-369.6$ & 0.45 \\
$375.5-379.5$ & $374.5-378.5$ & 0.54 \\
$380.1-384.2$ & $379.5-383.5$ & 0.17 \\
\hline
\end{tabular}

